\title{
Haematological Profile of Rats Administered With Aqueous Leaf Extract of Moringa Oleifera Following Thermooxidixed Palm Oil Diet Induced Toxicity
}

\author{
${ }^{1}$ Okwari, O. O, ${ }^{2}$ Emerole C.G, ${ }^{3}$ Dasofunjo K , ${ }^{4}$ Ezugwu H.C and ${ }^{1}$ Obi .J \\ ${ }^{I}$ Department of Physiology, Cross River University of Technology, Okuku, Nigeria \\ ${ }^{2}$ Optometry Unit Eye Clinic, Federal Medical Centre, Owerri, Nigeria \\ ${ }^{3}$ Department of Medical Biochemistry, Cross River University of Technology, Okuku, Nigeria \\ ${ }^{4}$ DepartmentChemical Sciences,University of Mkar,Mkar,Nigeria
}

\begin{abstract}
In assessing the effect of haematological parameters of rats administered with aqueous leaf extract of Moringa oleifera following thermooxidixed palm oil induced toxicity. Twenty-five (25) Female rats weighing 150-170g body weight were assigned randomly into five groups: A-E of 5 rats, after permission was granted by the Collage Ethical Committee on Experimental Animals. Groups A serves as control received rat chow and water, Group B was fed with fresh palm oil diet (Diet I), Group C was fed with thermoxidized palm oil diet (diet II), Group D was fed with fresh palm oil diet and $600 \mathrm{mg} / \mathrm{kg}$ body weight aqueous Moringa oleifera leaf orally for 28days, Group E received thermoxidized palm oil diet and $600 \mathrm{mg} / \mathrm{kg}$ body weight orally for 28days. They were allowed free access to water and standard feeds ad libitum throughout the experimental periods. The animals were housed in stainless cages at temperature of $28 \pm 20^{\circ}$ Cand $12 \mathrm{hrs}$ dark cycle and humidity of $60 \%$. After $28^{\text {th }}$ day of feeding, the rats were allowed an overnight fast. They were anaesthetized with chloroform/diethylether mixture, their thorax was opened and blood was withdrawn by cardiac puncture with sterilesyringeinto EDTA sample bottle for haematological studies.Sequel to this, the bioactive component of Mo ringa oleifera was determined using standard methods.Results shows the presence of alkaloids, glycosides, sapo nins, tannins, flavonoids, reducing compounds, polyphenol, titerpenes, steroid with highest concentration of flav onoids and polyphenols while anthraquinones, hydroxyl methyl and phlobatannins are notdetected.Hematologic al result from $R B C s$ showed significant increase $(P<0.001)$ in $F P O, F P O+M O$ and $T P O+M O$; WBC were significantly increased in TPO, FPO+MO and TPO+MO. Platelets, $H B$ and $H C T$ were significantly reduced in $T P O$ but were significantly $(P<0.001)$ higher in $F P O+M O$ and $T P O+M O . M C V$ and $M C H C$ were significantly $(P<0.001, P<0.05)$ increase in test groups compared with the control. The granulocyte $\%$ were significantly reduced $(P<0.001)$ in $T P O$ and $F P O+M O$ but were increased in FPO while monocyte were significantly reduced in test groups compared with the control. Lymphocytes were significantly $(P<0.05)$ increased in test groups compared with control. The results are indications of its haematopoietic and erythropoietic effect which suggests that the bioactive component of Moringa oleifera might possess a chelative or scarvengive effect on the TPO diet.
\end{abstract}

Keywords:Bioactive components, EDTA, Heamatological parameters ,Moringaoleifera, Thermooxidized palm oil.

\section{Introduction}

Formation of free radicals result from the by-product of many normal cellular reactions including energy generation,breakdown of lipids and proteins and inflammatory processes[1] as well as intracellular accumulation resulting from exogenous pr-oducts such as environmental pollutants that cannot be broken down by cells [2]. They may accumulate transiently causing reversible damage or permanently resulting in irreversible damage following their cytotoxic effects. It has been theorized that they are involved in degenerative disorders such as Alzheimer dementia and Parkinsonism plague formation in atherosclerosis and cancer [3].Free radical injury has been known to be the final pathway to tissue damage by injurious agents. Uncontrolled free radical formation damage cell membranes, cross-link proteins, damage the nucleic acid that make up DNA. An imbalance between free radicals generation and free radicals scavenging system results in oxidative stress. Free radical mediated damage contributes to such varied process as chemical injury, ischemia-reperfusion injury $[4,5,6,7]$ mitochondrial dysfunction [8,9], loss of membrane phospholipid ,cytoskeletal abnormalities. [8].Haemoglobin alteration in auto mechanics exposure to motor spirit fumes [10] has been reported.

The list of chemicals/substances that may cause cell injury defies compilation [11]. Simple chemicals such as glucose and salt in hypertonic concentration may cause cell injury directly or by deranging electrolyte homeostasis of cells. Nutritional excesses and nutritional deficiencies $[12,13]$ such as obtain in urbanised or rural 
areas have become important causes of ill health. Whether over nutrition or under nutrition the common position of the diet makes a significant contribution to a number of diseases.

Thermally oxidised palm oil (TPO) remains the one form of palm oil used by road-side food, fish sellers. Normally palm oil is consumed either freshly or as thermally oxidized. It is thermally oxidized when the fresh form is subjected to several rounds of heating at high temperature. This way the exogenous fumes are inhaled and/or taken into the body by those who prepare as well as when taken in diets. Its cytotoxic and destructive byproducts are known to be injurious to cells, tissues and organs [11]. Long term consumption of oxidised oils and fats causes devastating physiological and biochemical effects [14]. Free radicals generated are said to be involved in the aetiology of disease state $[15,16,17]$.

Moringa oleifera, family moringaceae is a native to sub-Himalayan region India, Pakistan, Asia Minor, Africa and Arabia [18,19].Moringa oliefera is widely cultivated and has become naturalized in many parts of the tropics [20]. All parts of the plant: root, back, fruit, seed, leaf, pods) have been reported to have medicinal, social, nutritional, industrial value $[21,22]$. The plant contains protein, vitamins, B-carotene, amino acids and various phenolics [23] which confer its use in man's health challenges.Moringa oleifera leaves are used for preparation of soup and additionally as antipyretic, antidiarrhea cases but how it affect blood cells remain to be researched. It is believed that inhaling oil fumes and consumption of thermally oxidized oil and fat induced free radicals which are injurious to the tissues and cause haematological disorders. Therefore, in this study it is necessary to investigate the effect of Moringa oleifera on blood cells of rats fed with thermoxidized palm oil diet.

\section{Collection of plant material}

\section{Materials and Methods}

The leaves of Moringa oleifera were collected in March, 2013 from Okuku,Yala, Local Government Area, Cross River State, Nigeria. The plant material was authenticated in the Department of Botany, University of Calabar, Nigeria. The leaves were washed with distilled water and sun dried, pulverised by electrical homogenizer into snuff-like powder and macerated 1:10 w/v solvent (water) and left for 12hrs, filtered using Whatman 1 filter paper. The filter was dried in an aerated oven at $45^{\circ} \mathrm{C}$ to constancy. The resulting extract was stored in screw-capped bottle until use.

\section{Evaluation of the crude phytoconstituent of Moringa oliefera leaf}

The screening of the leaf extract for the presence of phytochemicals was carried as described using standard methods: alkaloids with Mayer and Dragendoffs reagent; flavonoid, with $\mathrm{Mg}$ and $\mathrm{HCl}$, ; tannin ferric chloride test;steroids;glycoside; polyphenol potassium ferocynate test ;saponin heated and cooled;phlobatinin test ;Anthraquinones Benzene and 10\% ammonia test ; hydroxy-antranquinone 5\% ammonia test; reducing Sugars Fehling's test[2021,22,23] .

\section{Animal}

Female rats (25) weighing 150-170g body weight were obtained from Animal House of the Department of Human Physiology, Faculty of Basic Medical Science, Cross River University of Technology were assigned randomly into five groups: A-D of 5 rats, after permission was granted by the Collage Ethical Committee on Experimental Animals. Groups A serves as control received rat chow and water, Group B was fed with fresh palm oil diet (Diet I), Group C was fed with thermoxidized palm oil diet (diet II), Group D was fed with fresh palm oil diet and $600 \mathrm{mg} / \mathrm{kg}$ Moringa oleifera leaf orally for 28days, Group E received thermoxidized palm oil diet and $600 \mathrm{mg} / \mathrm{kg}$ MOLE orally for 28days. They were allowed free access to water. The animals were housed in stainless cages at temperature of $28 \pm 20$ Cand $12 \mathrm{hrs}$ dark cycle and humidity of $60 \%$.

\section{Preparation of thermoxidized palm oil and formulation of diets.}

Five (5) litres of fresh palm oil was purchased from Okuku market, Yala Local Government Area, Cross River State, Nigeria was divided into 2 equal portions: one portion was subjected to thermal oxidation and the other was used as fresh. These forms are the two states palm oil is used for cooking. Palm oil was heated at $150{ }^{\mathrm{O}} \mathrm{C}$ in stainless pots for $20 \mathrm{mins}$ and allowed to cool for $5 \mathrm{hrs}$. This was done five times. In most West African diet the level of palm oil is $15 \%$ [24], $15 \mathrm{~g}$ of the cooled thermoxidized palm oil was mixed with $85 \mathrm{~g}$ of rat feed. This is (diet II). On the other hand $15 \mathrm{~g}$ of fresh palm oil was mixed with $85 \mathrm{~g}$ of rat feed form (diet I). All diets were stored in dark container to prevent further oxidation of oil content. 


\section{Collection of blood}

After $28^{\text {th }}$ day of feeding, the rats were allowed an overnight fast. They were anaesthetized with chloroform/diethyl ether mixture, their thorax was opened and blood was withdrawn from the heart with sterile syringe into EDTA sample bottle for haematological studies.

\section{Haematological Analysis of blood samples}

Analysis of blood samples was done using automated machine VITROST DT System: Vitros DTSC II module. Johnson Johnson, UK, 2004

\section{Statistical analysis}

Data was expressed as mean \pm SEM. Student $t$-test was used to compare means. P values of 0.05 were accepted significant.

\section{Results}

The result reveals that aqueous extract of Moringa oleifera contain bio active phytonutrients like Alkaloids, Glycosides,Saponins, Tannins, Flavonoids, Reducing compound,Polyphenol, Phlobatannins,Triterpen es, Steriod,though,polyphenols and flavonoids appears in higher concentration while Anthraquinones, Hydroxymethyl are not detected(Table 1). RBCs showed significant increase $(\mathrm{P}<0.001)$ in $\mathrm{FPO}, \mathrm{FPO}+\mathrm{MO}$ and $\mathrm{TPO}+\mathrm{MO}$; WBC were significantly increased in TPO, FPO+MO and TPO+MO. Platelets, HB and HCT were significantly reduced in TPO but were significantly $(\mathrm{P}<0.001)$ higher in FPO+MO and TPO+MO. MCV and MCHC were significantly $(\mathrm{P}<0.001, \mathrm{P}<0.05)$ increase in test groups compared with the control. The granulocyte \% were significantly reduced $(\mathrm{P}<0.001)$ in $\mathrm{TPO}$ and $\mathrm{FPO}+\mathrm{MO}$ but were increased in FPO while monocyte were significantly reduced in test groups compared with the control. Lymphocytes were significantly $(\mathrm{P}<0.05)$ increased in test groups compared with control (Table 2$)$.

Table 1: Phytochemical contents of Moringa oleifera leaf

\begin{tabular}{lc}
\hline Chemicalconstituent & Aqueousextract \\
\hline Alkaloids & + \\
Glycosides & + \\
Saponins & ++ \\
Tannins & + \\
Flavonoids & +++ \\
Reducing compound & + \\
Polyphenol & +++ \\
Phlobatannins & - \\
Triterpenes & + \\
Steriod & + \\
Anthraquinones & - \\
Hydroxymethyl &
\end{tabular}

\begin{tabular}{ll}
\hline Key: & \\
+ & Present \\
++ & Present in excess \\
+++ & Present in much excess \\
$\quad-$ & Absent
\end{tabular}


Table 2: Result of Haematological Analysis of Thermo oxidized Palm Oil Diet

\begin{tabular}{llllll} 
Parameter & Ctrl & FPO & TPO & FPO+MO & TPO+MO \\
\hline RBC $\left(\times 10^{9} / \mathrm{L}\right)$ & $6.27 \pm 0.21$ & $6.84 \pm 0.26^{* *}$ & $5.74 \pm 0.17^{* *}$ & $8.00 \pm 0.10^{* *}$ & $7.66 \pm 0.07 *$ \\
WBC $\left(\times 10^{6} / \mathrm{L}\right)$ & $6.17 \pm 0.33$ & $5.13 \pm 0.24$ & $7.60 \pm 0.20^{*}$ & $8.44 \pm 0.24^{* *}$ & $9.02 \pm 0.03^{* *}$ \\
$\mathrm{PLT}\left(\times 10^{6} / \mathrm{L}\right)$ & $469 \pm 3.80$ & $439.17 \pm 1.19^{* *}$ & $426.33 \pm 6.80^{*}$ & $539.36 \pm 6.80^{*}$ & $536.36 \pm 15.8^{* *}$ \\
$\mathrm{HB}(\mathrm{g} / \mathrm{dl})$ & $13.02 \pm 0.25$ & $13.05 \pm 0.25$ & $10.77 \pm 0.25^{* *}$ & $13.16 \pm 0.24^{*}$ & $13.18 \pm 0.10^{*}$ \\
$\mathrm{HCT}(\%)$ & $40.4 \pm 0.69$ & $41.18 \pm 0.49$ & $34.71 \pm 0.25^{* *}$ & $42.04 \pm 0.06^{*}$ & $42.62 \pm 0.04^{*}$ \\
$\mathrm{MCV}(\mathrm{fl})$ & $45.50 \pm 0.24$ & $54.67 \pm 0.33^{* *}$ & $52.89 \pm 0.20^{* *}$ & $51.67 \pm 0.73^{*}$ & $54 \pm 0.45^{* *}$ \\
$\mathrm{MCH}(\mathrm{pg})$ & $17.76 \pm 0.61$ & $17.73 \pm 0.20$ & $16.77 \pm 0.15$ & $16.63 \pm 0.30$ & $17.27 \pm 0.29$ \\
$\mathrm{MCHC}(\mathrm{g} / \mathrm{dl})$ & $30.63 \pm 0.01$ & $31.75 \pm 0.57 *$ & $30.60 \pm 0.25$ & $30.68 \pm 0.08$ & $31.73 \pm 0.17^{*}$ \\
GRAM $(\%)$ & $20.28 \pm 0.04$ & $21.45 \pm 0.14^{*}$ & $15.42 \pm 0.13^{* *}$ & $14.07 \pm 0.05^{*}$ & $20.20 \pm 0.08$ \\
MONO(\%) & $16.28 \pm 0.08$ & $10.67 \pm 0.09^{*}$ & $9.37 \pm 0.10^{*}$ & $12.37 \pm 0.15^{*}$ & $10.67 \pm 0.08^{* *}$ \\
LYM $(\%)$ & $6.03 \pm 0.03$ & $6.35 \pm 0.12^{*}$ & $17.45 \pm 0.18^{* *}$ & $7.13 \pm 0.58^{*}$ & $9.88 \pm 0.31^{* *}$
\end{tabular}

Data expressed as mean $\pm \mathrm{SEM}, \mathrm{n}=6, *=\mathrm{P}<0.05, * *=\mathrm{P}<0.01$, $* * *=\mathrm{P}<0.001$, $\mathrm{ns}=$ not statistically significant.

\section{Discussion}

Drugs and or chemicals induced anaemia [25] as well as free radical induced injury[1,26] on cells and tissue has been known. We fed rats with thermally oxidized palm oil diets for 28 days with daily administration of Moringa oleifera $600 \mathrm{mg} / \mathrm{kg}$ body weight oral dose to study the effect on haematological parameters most especially on the TPO+MO groups.

The results showed that red blood cell counts were significantly higher in the Moringa oleifera feed groups compared with FPO, TPO and control. An increased red blood cell in male rats has been reported by $[27,28]$.This suggests that the leaf extract contain agents that induced the production of red blood cells or enhances erythropoiesis by the bone marrow. Although, the mechanisms involved were not studied. Red blood cells carry oxygen to various parts of the body by haemoglobin [10]. Haemoglobin content in the Moringa oleifera fed groups was significantly higher. This increase may arise as a result of increase red blood cell count and possibly the mineral content of the leaf extract especially iron content, an increase in iron supply is necessary to elevate the haemoglobin content. This suggests that the leaf may be useful in management of anaemic conditions, supporting the acclaimed folkloric usage that Moringa oleifera leaf relieves conditions of malaria and typhoid.

The haematocrit of the extract fed rats were significantly higher compared with TPO and Control. The measure of haematocrit is the number and size of red blood cells [26]. Similar increase was noted by [29].The result suggests an increase in volume of cells which is confirmed by the increase in mean cell volume (MCV). A high MCV is an indication of macrocytic anaemia suggesting vitamin $\mathrm{B}_{12}$ and folate deficiency but it is not clear whether the biochemical consequence of cobalamin is one of inability to synthesise new DNA bases or defect in cell division seen in cytotoxic drugs or haematological disease in the marrow such as myedysplasia[29]. The mean cell haemoglobin concentration (MCHC) was seen to be increased in TPO+MO group. This suggests hyperchromasia although blood films were not studied. The presence of macrocytes, abnormally rounded cells with increased cell thickness greater than normal to increased MCHC [25] as seen in TPO+ MO.The Moringa oleifera fed groups showed increased platelet count this result agree with that of [30]. [31], observed that Epo and Tpo are closely related in the production of red blood cells and platelets. Epo and Tpo are identical at the N-terminal region and therefore have some effect on erythropoiesis, although the exact role is not clear. It is recognised that several types of anaemia are associated with arise in platelets. Increase in total white blood cell count may be beneficial as they are vital in the body's defence mechanism [32].

Taken separately, the TPO+MO group exhibited mark changes in the haematological parameters indicating that the insult on the thermoxide palm oil diet fed rats has been ameliorated. Scientists continue to investigate the use of free radical scavengers to protect against cell injury during periods when protective cellular mechanisms are impaired [33]. Antioxidants are involved in the prevention of free radical cellular damage, the common pathway of a variety of diseases. The subdued effect of free radicals in the TPO+MO group must be due to the presence of such radical scavengers as zeatin, quercetin, beta sitosterol,caffeoylquinic acid and kaempferol, important for Moringa oleifera medicinal values. These antioxidants in the Moringa oleifera act as defence system against free radical damage.

This report is in accordance with the report of [33,34].

In conclusion, Moringa oleifer a aqueous leaf extract given to rats orally at the dose of $600 \mathrm{mg} / \mathrm{kg}$ body weight improvedfullblood count in female rats. MCV, MCHC were be increased indicating the presence of macrocytes and hyperchromasia respectively. The extract should be taken be with caution despite of its anitoxidant and haematopoietc effect. 


\section{References}

[1], E.W Carol Cell and Tissue Characteristics.In Porth C.M Kumet M.P eds.Pathophysiological Concept of Altered Health States. $6^{\text {th }}$ edn pp. 102-105.Philadelphia.Lippincott and Williams and Wilkins 2002.

[2] R.SCotran, .V Kumar C .Collins.Robbins Pathological Basis of Disease 7th edn Saunders pp. 6-14,424- 428 Philadelphia W.B Saunders, 1999

[3] V .Kumar, A.K Abbas, N Fausto Robbins and CotranPathalogic Basis of Disease $7^{\text {th }}$ edn $\quad$ Saunders pp 13- 34,2006

[4] Droge W (2002).Free Radical in Physiological Control of Cell Function:PhysiologicalRev 82:47 - 95

[5] K Hensley,K.A,RobbisonS.PGabbita, .S SalsmanR.A Floyd Reactive Oxygen Species,CellSignaling and Cell Injury.FreeRadicBiol.Med 28: 2000,1456 - 1462.

[6] D Salveminiand.SCuzzocrea.Superoxide, Superoxide dismutase and Ischaemic Injury. Current Opinion Investig. Drug 3:2002,886-895.

[7] C Li and R.M Jackson.Reactive Species Mechanism of Cellular Hypxia - Reoxygenation Injury.Am Journal of Physiology Cell physiology 282: 2002,C227 - c421.

[8] D.D Newmeyerand .S Fergusamiller.Mitochondria: releasing power for Life and unleashing the Mechanisms of death Cell 112: $2003,481-486$.

[9] J.S Kim, J.J HEL,Lemasters. Mitochondrial Permeability,Transition, a Common Pathway to necrosis and Apoptosis. Biochem.Biophysic.Res.Commun. 304: 2003,463 - 470.

[10] N.EUdonwa, E.K UkoB.M,IkpemeA.IIbangha, B.O Okon. Exposure of Petrol Station attendant and auto- mechanics to premium motor spirit fumes in Calabar Nigeria.J.EnvironPublic Health. 1-5,2009

[11] S. Meredith.Freeradicals:Frien or Foe.Medical Digest 10(3) :1984,23-25

[12] H Lunec .Oxygen Radicals, Their Measurement and Role in major diseases JIFCC 14(2): 1992,58- 63

[13] P.EEbong, D.U OWU and E.U Isong,Inflence of Palm Oil (Elaesisguineesis) on Health.Plant food for Human Nutrition(formally Qualitasplanturum) 53(3): 1999,209-222

[14] M.A Somali,M.A,BanediS.S Al-Faimani. Composition and Characteristics of Moringaoleiferaseed and oil .J.Am.Chem.Sco.61: 1984,85-86

[15] M.H Mughal, .G Ali, P.S Srivastaand .MIgbal , Improvement of drumstic (M.pterygospermagaectin) A unique source of food and medicine of food and medicine through tissue culture.Harmal.Med 42: 1999,37-42

[16] J Fahey.Review of Medical Evidence for Its Nutritional,Therapeutic and Prophylactic Properties. Trees of Life.1-5,2005

[17]. NKasoloK,G.S.Bimenya,K.L,Ojo J.W Ogwal-Okeng(2012).Sub acute toxicity evolution of Moringaoleifera leaves of aqueous and ethanol extracts in Swiss albino rats Int.J.Med Plant Res 4: 74-80

[18] H Delisleand S Bakari. Provitamin: A content of Traditional Green Trees from Niger. Cahier Agriculture 6: 1997,553-560

[19] A,Farooq .L.Sajid, A Mohammad and G AnwaniHassan.Moringaoleifera.A food plan plant with multiple medicinal uses. Phytotherapy Research 21: 2007,17-25

[20] T.E Harbone,PhytochemicalMethods.A Guide to Modern Techniques of Plant Analysis, London Chapman and Hills p $235,1998$.

[21] L.GSilva,.S,LeeID.A Kinghorn. Special problem with extraction of plants In: Methods in Biotechnology natural products isolation Cannell JPR ed. Humana Press Inc. Totowa, New Jessey U.S.A 4:329-363,1998

[22] J Houghton and.ARaman. Laboratory Handbook for Fractionation of natural extracts chapman and Hill London P 199,1998

[23] W.C Evans .Trease and Evans.Phamacology $13^{\text {th }}$ EdnBaillere Tindal W.B Saunderpp 176 - 180,2002

[24] I.B Umoh. Changes in nutritive values of some Nigeria diets after cooking by certain South Eastern traditional method Ph.D Thesis, University of Ibadan, Nigeria,1972

[25] S.M,Lewis,.J.BainB, I Bates ,Dacll and Lewis practical Haematology $.9^{\text {th }}$ edn. Church Livingstonepp 66-82,2002

[26] M.C.Porth.andP.M Kunert.Pathophysiology Concepts of altered health states. $6^{\text {th }}$ edn New York Lippincott William and Wilkins pp. $101-103,2002$

[27] E Soyinka ,The Review of Natural Products with Antibiotic Activity .Natural Product Report 20: 2004,56-79

[28] K.E Barrette, S.M Barman, and Books H.L, Ganongs Review of Medical Physiology 23rd edn .McGraw Hill Lange. p 525.2013

[29] J.O Craig D.B,McClelland and C.A Ludlam.Blood Disorders .In Boon N.A College NR Walker B.R eds.Davidsons Principles and practice of medicine 20 ${ }^{\text {th }}$ edn pp1999-1023. Livingstone Elsevier Edinburg2006

[30] J.O.Owolabi, EOpoola, E.A.Carton-Martins.Healing and Prophylactic Effect Moringa oleifera Leaf extract on Lead Extract on Induced Damage on Haematological and bone Marrow Element In Adults Rat Models Scientific 1: 2012,386- 395

[31] E.CGordon Smith .Erythropoiesis.InHoff brandA.V,Levis S.M,Tuddenham EGD eds Postgraduate Haematology $4^{\text {th }}$ edition.Butterworth.Heinemann Oxford p 19,1999

[32] A.HGilani,. KAftab,K.ShaheenAntispamidic Activity of active principle from Moringa oleifera.In natural drug and digestive tract F.Capasso and N Mascoloeds, 2000

[33] S .FaizB.S,Siddiqui, R. Shaheen, K. Aftab, A.H Gilani, Novel hypotensive agents niaziminA,niazin B from Moringaoleifera.isolation of first carbamate glycosides Moringaoleifera.Phytochemistry 38(4): 1992, 957-963

[34] P Di Simplicio, E.Lupisand R.Rossi Different mechanism of formation of Glutathione protein mixed disulphides of diamine and tert-butylhydroper oxide in rat blood.Biochemical et BiopysicaActa 1289 (2) :1996, 252-260 